\title{
Prinsip Netralitas Aparatur Sipil Negara Dalam Pemilihan Kepala Daerah
}

\author{
Sutrisno \\ Fakultas Syariah IAIN Surakarta \\ Jl. Pandawa Pucangan Kartasura Sukoharjo \\ trisno_061@yahoo.com
}

Received: 6 Agustus 2019; Accepted: 17 Desember 2019; Published: 17 Februari 2020

DOI: 10.20885/iustum.vol26.iss3.art5

\begin{abstract}
This study aims to determine the factors, weaknesses and components that affect the neutrality of the State Civil Apparatus (ASN) in the recent regional election. This research is a non-doctrinal legal research/socio-legal research/sociology of law study by using the statutory and case approaches in the recent elections in Surakarta City, Sragen Regency and Bantul Regency. The nature of this research is descriptive analysis which intends to provide an overview of the existing condition of the neutrality of ASN in carrying out tasks related to the operation of law in the community. The results of the study concluded that in Surakarta, Sragen, and Bantul, some ASN were not neutral with several contributing factors including personal loyalty, familiar relations, career ambitions, ambiguity of regulations, ineffective law enforcement and low awareness of the community in civilizing the law. The embodiment of the neutrality of ASN in the regional elections can be done by optimally involving the role of several related institutions, including the State Civil Apparatus Commission (KASN), Bureaucratic Leadership, Regional Inspectorate, the Regional Civil Service Agency, the Election Commission and the Election Supervisory Body.
\end{abstract}

Keywords: Neutrality ASN; regional election

\section{Abstrak}

Penelitian ini bertujuan untuk mengetahui faktor-faktor, kelemahan-kelemahan dan komponen yang memengaruhi netralitas Aparatur Sipil Negara (ASN) dalam pemilukada saat ini. Penelitian ini merupakan penelitian hukum non doktrinal/socio-legal research/sosiologi hukum dengan menggunakan metode pendekatan perundang-undangan (statutory approach) dan pendekatan kasus (case approch) dalam pilkada di Kota Surakarta, Kabupaten Sragen dan Kabupaten Bantul. Sifat penelitian ini deskriptif analisis yang bermaksud memberikan gambaran existing condition netralitas ASN dalam menjalankan tugas terkait dengan bekerjanya hukum di masyarakat. Hasil penelitian menyimpulkan bahwa di Surakarta, Sragen, dan Bantul, beberapa PNS tidak netral dengan beberapa faktor penyebab antara lain, loyalitas ASN, hubungan kekeluargaan, ambisi karir jabatan, ambiguitas peraturan, lemahnya penegakan hukum, serta rendahnya kesadaran masyarakat dalam berbudaya hukum. Pewujudan netralitas ASN dalam Pilkada dapat dilakukan dengan melibatkan secara optimal peranan beberapa institusi terkait, antara lain Komisi Aparatur Sipil Negara (KASN), Pimpinan Birokrasi, Inspektorat Daerah, dan Badan Kepegawaian Daerah, Komisi Pemilihan Umum, dan Badan Pengawas Pemilu.

Kata-kata Kunci : Netralitas aparatur sipil negera; pemilihan kepala daerah 


\section{Pendahuluan}

Komisi Pemilihan Umum (KPU) menetapkan 270 kabupaten/kota menggelar pilkada serentak pada 2020. Adapun 270 daerah tersebut meliputi 9 pemilihan gubernur, 224 pemilihan bupati dan 37 pemilihan walikota. Pendaftaran pasangan calon akan diselenggarakan pada 16 Juni 2020 sampai dengan 18 Juni 2020, sedangkan masa kampanye akan dilaksanakan pada 11 Juli 2020 sampai dengan 19 September 2020. ${ }^{1}$ Masa kampanye inilah yang berpotensi menyebabkan ASN rentan terhadap pengaruh para calon kepala daerah sehingga profesionalitasnya tergerus.

Pemilihan Kepala Daerah (Pilkada) dapat memicu pemanfaatan birokrasi untuk kepentingan politik dalam Pilkada. Di berbagai daerah, calon kepala daerah petahana hampir selalu memobilisasi ASN untuk memenangkan dirinya. Seharusnya birokrasi dibebaskan dari pengaruh dan keterjalinan ikatan politik dengan kekuatan-kekuatan politik, sehingga pelayanan kepada masyarakat yang diberikan oleh birokrasi netral tidak memihak dan obyektif. Birokrasi yang memihak atau tidak netral dapat melahirkan korupsi politik yang justru mengubah proses pilkada diwarnai tindakan-tindakan tidak terpuji. ${ }^{2}$

Pemilihan secara langsung bukanlah hal yang baru bagi rakyat Indonesia, karena sebelumnya telah dilaksanakan pemilihan Presiden dan Wakil Presiden secara langsung juga. Pemilihan kepala daerah secara langsung oleh rakyat di daerah telah dijalankan sejak berlakunya Undang-Undang Nomor 32 Tahun 2004 tentang Pemerintah Daerah.

Penyelenggaraan Pilkada secara langsung telah membawa perubahan terhadap budaya pemerintahan di tingkat daerah, dalam hal ini reposisi relasi birokrasi dengan politik, khususnya masalah netralitas birokrasi terhadap politik. ${ }^{3}$ Pilkada secara langsung dan serentak merupakan situasi yang berbeda, mengingat besarnya kewenangan daerah sejak digulirkannya otonomi daerah. Kepala daerah

\footnotetext{
${ }^{1}$ Lampiran Peraturan Komisi Pemilihan Umum Republik Indonesia Nomor 15 Tahun 2019 tentang Tahapan, Program, dan Jadwal Penyelenggaraan Pemilihan Gubernur dan Wakil Gubernur, Bupati dan Wakil Bupati, dan/atau Wali Kota dan Wakil Wali Kota Tahun 2020

2 Moh Mahfud MD, Evaluasi Pemilukada dalam Perspektif Demokrasi dan Hukum. Dalam Demokrasi Lokal Evaluasi Pemilukada di Indonesia, Konstitusi Press, Jakarta, 2012, hlm. 12

${ }^{3}$ Sudiman Dalim, Politisasi Birokrasi Netralitas dan Mobilitas PNS dalam Pilkada, Titian Pena Abadi, Jakarta, 2010, hlm. 5
} 
paling berperan dalam menentukan keberhasilan pembangunan suatu daerah. Dengan kata lain masyarakat lebih banyak berharap kepada kepala daerah dalam memperbaiki kondisi yang telah ada.

Pilkada untuk wilayah Jawa Tengah pada 2015 diadakan secara serentak di 21 daerah kabupaten/kota. Wilayah Soloraya meliputi, Solo, Boyolali, Sukoharjo, Wonogiri, Sragen dan Klaten. Agar Pilkada berjalan dengan baik dan menghasilkan kepala daerah yang berkualitas sesuai harapan masyarakat, maka dibutuhkan sistem, manajemen, dan penegakan hukum. ${ }^{4}$ Keberhasilan pelaksanaan Pilkada tidak terlepas dari peranan penyelenggara, yaitu Badan Pengawas Pemilu, Panwascam, Panitia Pemilihan Kecamatan (PPK) sampai pada Panitia Pemungutan Suara (PPS).

Penulis melakukan penelitian mengenai netralitas ASN di Kota Surakarta, Kabupaten Sragen, dan Kabupaten Bantul. Lokasi penelitian ini menarik, karena didukung data dari Bawaslu RI yang disampaikan oleh Koordinator Divisi Pengawasan Bawaslu dalam seminar nasional dengan tema Netralitas ASN dalam Pilkada serentak, yang diselenggarakan di Jakarta pada tanggal 20 April 2016. Disebutkan bahwa di Kabupaten Bantul ada 16 pejabat diduga tidak netral yang terdiri dari Kepala BKD, Inspektorat, Sekretaris Daerah, Kepala Dinas/Kantor, beberapa Camat, Kabag dan Lurah. Di Kabupaten Sragen pejabat yang diduga tidak netral adalah camat Sambirejo, Kepala Bidang Bappeda dan Lurah. ${ }^{5}$ Sedangkan di Kota Surakarta berdasarkan data laporan Panwaslu terdiri antara lain Camat Jebres, Lurah Pucangsawit, Mangkubumen, Jebres, Tegalharjo dan salah seorang Kabid Dinas Sosial dan Tenaga Kerja (Dinsosnakertran). ${ }^{6}$

Persoalan netralitas ASN memang masih sering timbul dalam Pilkada. Netralitas ASN dalam kontestasi politik merupakan kajian hukum kepegawaian. Sebagaimana yang dikemukakan oleh Utrecht, bahwa hukum administrasi menguji hubungan hukum istimewa yang diadakan untuk memungkinkan para

${ }^{4}$ Didik Supriyanto, Penataan Kembali Sistem Pemilihan dalam Pemilukada. Dalam Demokrasi Lokal, Konpress, Jakarta, 2012, hlm. 211

${ }^{5}$ Bawaslu RI. Disampaikan dalam Seminar Nasional 20 April 2016 di Jakarta.

${ }^{6}$ Laporan Pelaksanaan dan Hasil Pengawasan Pemilihan Walikota dan Wakil Walikota Tahun 2015 
pejabat (amsdragers) administrasi negara melakukan tugas mereka yang khusus. ${ }^{7}$ Pada satu sisi, ASN adalah aparatur pemerintah yang dituntut melaksanakan tugas pemerintahan untuk memberikan pelayanan publik, sedangkan di sisi lain PNS juga anggota masyarakat yang memiliki kepentingan-kepentingan politis maupun ekonomis yang menyangkut pilihannya dalam Pilkada. Seringkali kepentingankepentingan tersebut lebih dominan sehingga yang diharapkan sebagai pemilihan yang jujur dan adil tidak terpenuhi.

Di era reformasi salah satu sikap Keputusan Munas ke-5 KORPRI yang merupakan satu-satunya organisasi PNS di luar kedinasan, menyatakan "PNS tidak melibatkan diri dalam kegiatan partai politik". Hampir semua bidang kehidupan diatur oleh peraturan perundang-undangan, melalui penormaan terhadap tingkah laku manusia hukum mencakup hampir semua bidang kehidupan manusia. ${ }^{8}$ Termasuk pengaturan dalam Pilkada, terdapat 3 regulasi yang mengatur yaitu Undang-Undang No. 5 Tahun 2014 tentang Aparatur Sipil Negara, Undang-Undang No. 10 Tahun 2016 tentang Pemilihan Gubernur, Bupati dan Walikota dan Peraturan Pemerintah No. 53 Tahun 2010 tentang Disiplin Pegawai Negeri Sipil. ${ }^{9}$

Pasal 9 ayat (2) Undang-Undang Nomor 5 Tahun 2014 tentang Aparatur Sipil Negara (UU ASN), menentukan bahwa Pegawai ASN harus bebas dari pengaruh dan intervensi semua golongan dan partai politik, sedang Pasal 12 menyatakan Pegawai ASN berperan sebagai perencana, pelaksana, dan pengawas penyelenggaraan tugas umum pemerintahan dan pembangunan nasional melalui pelaksanaan kebijakan dan pelayanan publik yang professional, bebas dari intervensi politik, serta bersih dari praktik korupsi, kolusi dan nepotisme.

Jika aparat birokrasi pemerintah dapat dijaga netralitasnya dalam pelaksanaan fungsinya, maka rakyat secara keseluruhan dapat terlayani dengan baik dan profesional. Birokrasi yang netral tidak mengutamakan dan memihak kepada salah satu kepentingan kelompok rakyat tertentu. Pemihakan kepada

\footnotetext{
7 Sri Hartini, "Penegakan Hukum Netralitas Pegawai Negeri Sipil (PNS)" Jurnal Dinamika Hukum Vol. 9. No. 3, September 2009, hlm. 259

${ }^{8}$ EsmiWarassih, Pranata Hukum Sebuah Telaah Sosiologis, Pustaka Magister, Semarang, 2014, hlm. 71

9 Harry Setya Nugraha, "Politik Hukum Pengaturan Netralitas ASN dalam Pilkada Tahun 2018", Jurnal Justisi Hukum ISSN2528-2638 Vol 3, No. 1, September 2018, hlm. 27-28
} 
kepentingan seluruh rakyat ini sama dengan melaksanakan demokrasi. Sedangkan keberpihakan birokrasi terhadap salah satu kekuatan partai politik yang sedang memerintah cenderung akan memberikan peluang terhadap suburnya penyalahgunaan kewenangan seperti korupsi, kolusi dan nepotisme. Berdasarkan uraian permasalahan di atas, maka penulis memandang perlu untuk melakukan penelitian mengenai Netralitas Pegawai Negeri Sipil dalam Pemilihan Kepala Daerah.

\section{Rumusan Masalah}

Berdasarkan uraian latar belakang di atas, penulis merumuskan permasalahan sebagai berikut: pertama, apakah penyebab ketidaknetralan Aparatur Sipil Negara terjadi dalam pemilihan kepala daerah? Kedua, bagaimana upaya untuk mewujudkan netralitas Aparatur Sipil Negara dalam pemilihan kepala daerah?

\section{Tujuan Penelitian}

Penelitian ini bertujuan untuk: pertama, untuk mengetahui penyebab Aparatur Sipil Negara cenderung bersikap tidak netral dalam pemilihan kepala daerah; kedua, untuk mengetahui upaya untuk mewujudkan netralitas Aparatur Sipil Negara dalam pemilihan kepala daerah.

\section{Metode Penelitian}

Jenis penelitian ini adalah penelitian hukum non doktrinal/penelitian hukum empiris atau penelitian hukum sosiologis/socio-legal research, yaitu penelitian hukum yang memperoleh data dari sumber data primer. ${ }^{10}$ Penulis memilih lokasi penelitian di 3 wilayah, meliputi Kota Surakarta, Kabupaten Sragen, dan Kabupaten Bantul. Alasan penulis memilih daerah ini berdasarkan data dari Koordinator Divisi Pengawasan Bawaslu RI (Bapak Daniel Zuchron) yang disampaikan dalam seminar nasional netralitas ASN dalam rangka mewujudkan Pilkada serentak 2017 pada 20 April 2016 di Jakarta. Kota Surakarta, Kabupaten Sragen dan Kabupaten Bantul terindikasi banyak PNS yang tidak netral pada saat Pilkada serentak 2015.

${ }^{10}$ M. Ali, Metodologi Penelitian Hukum, Penelitian Hukum Hukum Empirik/Nondoctrinal dan Analisis Statistik, Surakarta, Unesa University Press, 2009, hlm. 17 
Sifat penelitian dalam ini deskriptif analisis bertujuan untuk mendeskripsikan secara sistematis, faktual dan akurat terhadap suatu populasi atau daerah tertentu, mengenai sifat-sifat; karakteristik-karakteristik atau faktor-faktor tertentu. ${ }^{11}$ Penelitian kualitatif yang menghasilkan data deskriptif berupa kata-kata tertulis atau lisan dari orang-orang dan perilaku yaang dapat diamati untuk diarahkan pada latar dan individu secara holistik/utuh. ${ }^{12}$ Penelitian ini menggunakan perpaduan pendekatan perundang-undangan (statute approach), dan pendekatan kasus (case approach).

\section{Hasil Penelitian dan Pembahasan}

\section{Faktor-faktor yang Memengaruhi Netralitas ASN dalam Pilkada}

Pilkada secara langsung oleh rakyat merupakan pewujudan pengembalian hak-hak dasar rakyat dalam memilih pemimpin di daerah. Rakyat memiliki kesempatan dan kedaulatan untuk menentukan pemimpin daerah secara langsung, bebas dan rahasia tanpa intervensi. ${ }^{13}$ Namun, pelaksanaan Pilkada tidak selalu berjalan ideal. ASN selaku abdi negara yang berkewajiban untuk memberikan pelayanan publik justru sering terkooptasi oleh kepentingan politik. Politisi maupun calon kepala daerah yang tidak negarawan sering memanfaatkan birokrasi untuk kepentingan politiknya. ${ }^{14}$

Salah satu tugas ASN adalah menyelenggarakan pemerintahan dan pembangunan dalam rangka usaha mewujudkan tujuan nasional. Tujuan nasional ini sebagaimana dimaksud dalam Pembukaan Undang-Undang Dasar Negara Republik Indonesia Tahun 1945, yaitu melindungi segenap bangsa Indonesia dan seluruh tumpah darah Indonesia dan memajukan kesejahteraan umum, mencerdaskan kehidupan bangsa dan ikut melaksanakan ketertiban dunia yang berdasarkan kemerdekaan, perdamaian abadi dan keadilan sosial.

${ }^{11}$ Ibid., hlm. 35

12 Sabian Usman, Dasar-dasar Sosiologi Hukum: Dilengkapi Proposal Penelitian Hukum (Legal Research), Yogykarta, Pustaka Pelajar, 2010 hlm. 382

13 Riri Nazriyah, "Implikasi Putusan MK Terhadap Netralitas PNS Dalam Pemilukada", Jurnal Konstitusi, Volume 6. Nomor 2, Juli 2008

${ }^{14}$ M. Adian Firnas, "Politik dan Birokrasi: Masalah Netralitas Birokrasi di Indonesia Era Reformasi" Jurnal Review Politik Vol. 06 No. 01, Juni 2016, hlm. 186 
Guna mencapai tujuan nasional diperlukan ASN yang penuh kesetiaan dan ketaatan kepada Pancasila, Undang-Undang Dasar 1945, Negara Kesatuan Republik Indonesia bersatu padu, cerdas, berdaya guna, bersih dan bebas dari pengaruh dan intervensi semua golongan dan partai politik. ASN sesuai fungsinya sebagai pelaksana kebijakan publik, pelayan publik, dan perekat pemersatu bangsa. Namun, kenyataan yang terjadi dalam Pilkada, sering kali ASN tidak bersikap netral. Hal ini dikarenakan adanya sejumlah faktor yang memengaruhi ketidaknetralan tersebut. Sebagaimana wawancara penulis dengan Ketua Bawaslu Kota Surakarta, Kabupaten Sragen dan Kabupaten Bantul, bahwa faktor sejarah dan sosial budaya, hubungan kekeluargaan, ambisi karir jabatan, ambiguitas peraturan, lemahnya penegakan hukum, serta masih rendahnya kesadaran masyarakat dalam berbudaya hukum.

\section{Faktor Loyalitas ASN}

Faktor Loyalitas ASN dalam birokrasi pemerintahan turut memengaruhi sikap ASN dalam perhelatan Pilkada. Sedari dulu kepala daerah memiliki kewenangan tertinggi dalam menentukan posisi pejabat struktural. Sementara Sekretaris Daerah sebagai pejabat administrasi pemerintahan tertinggi dan pimpinan tertinggi bagi ASN di daerah harus tunduk dan loyal kepada kehendak kepala daerah. ${ }^{15}$ Hal ini juga terjadi di Kabupaten Bantul calon bupati petahana mengundang para pejabat dalam acara deklarasi yang dilakukan PDIP pada 14 Juni di Lapangan Trirenggo Bantul dari 14.00 WIB sd 17.00 WIB. ${ }^{16}$ Di Kabupaten Sragen, seorang Camat Sambirejo rela menyediakan ratusan paket sembako untuk mendukung calonnya. ${ }^{17}$

Sejak dahulu isu mutasi jabatan menjelang Pilkada selalu dimunculkan secara politis sebagai instrumen untuk mengendalikan loyalitas pejabat struktural maupun fungsional di lingkungan pemerintah daerah. Kedekatan personal dan loyalitas antara ASN dengan kepala daerah dijadikan sebagai alat ukur utama dalam penempatan seseorang pada jabatan struktural sebuah kantor, dinas,

\footnotetext{
11 Juli 2017

15 Wawancara dengan Sri Sumanta. Ketua Panitia Pengawas Pilkada Kota Solo Tahun 2015, pada tanggal

${ }^{16}$ Wawancara dengan Imam Subardiyoso. Sekretaris BKD Kab. Bantul, pada tanggal 26 September 2017

17 Wawancara dengan Slamet Basuki. Ketua Panitia Pengawas Pilkada Kab. Sragen, 9 Mei 2017
} 
lembaga atau instansi. Sedangkan faktor profesionalitas dan integritas tidak lagi masuk sebagai sebuah pertimbangan utama bahkan cenderung diabaikan.

Pilkada di tiga daerah yaitu Sragen, Solo, dan Bantul pada 2015 memunculkan bupati/walikota sebagai calon kepala daerah petahana. Situasi ini menimbulkan titik singgung antara logika kekuasaan dengan logika birokrasi yang menciptakan polarisasi di slingkungan birokrasi. Budaya loyalitas birokrasi antara atasan dan bawahan serta dorongan kekuasaan untuk meraih keuntungan jabatan birokrasi, menimbulkan aturan netralitas kerap dilanggar oleh para ASN yang mendukung petahana. Tuntutan untuk loyal terhadap atasan (kepala daerah) sering dijadikan sebagai alasan, padahal sebenarnya ASN sedang terjebak dalam permainan politik kepala daerah yang tengah mencalonkan kembali untuk periode berikutnya.

\section{Hubungan Kekeluargaan}

Hubungan kekeluargaan antara ASN dengan calon kepala daerah tentu sangat memengaruhi netralitas. Hal ini sangat berpengaruh dalam penentuan sikap politik PNS. Jika PNS mempunyai saudara yang terlibat dalam pencalonan kepala daerah, tentunya mereka tidak akan membiarkan sudaranya berjuang sendiri dalam mencapai cita-citanya untuk terpilih sebagai bupati/walikota. Kasus ini terjadi di Kabupaten Sragen dimana Camat Sambirejo Suhariyanto yang masih ada hubungan keluarga dengan calon petahana mengkoordinir pembagian sembako untuk dibagikan kepada masyarakat, namun ketahuan dari tim lain kemudian dilaporakan ke Panwas yang akhirnya oleh Pengadilan Negeri Sragen dinyatakan bersalah dijatui hukuman 1 bulan penjara dan denda Rp. 1.500.000,00.18 Di Kabupaten Bantul dan Kota Surakarta penulis tidak menemukan faktor hubungan kekeluargaan antara calon kepala daerah dengan PNS yang mendukung.

\section{Ambisi Karir Jabatan}

Pilkada secara langsung dapat memunculkan kelompok masyarakat yang mendukung dan tidak mendukung dan ada juga kelompok masyarakat yang menjadi relawan atau bukan relawan. ASN pun juga terbagi dalam beberapa kelompok. Salah satu kelompok adalah kelompok birokrat yang secara tegas maupun sembunyi-sembunyi menempatkan diri pada kelompok salah satu 
kandidat kepala daerah. Kelompok ini cenderung memberikan dukungannya terhadap calon kepala daerah dengan mengerahkan tenaga dan sumber daya birokrasi. Para ASN berusaha menanam jasa kepada kandidat dengan harapan kepentingan ekonomi, pengamanan jabatan serta perolehan jabatan yang lebih tinggi apabila kandidat yang didukungnya berhasil terpilih.

Ketika kandidat yang didukung menang dalam pemilihan, maka biasanya ASN yang sebelumnya berjasa mendukung, kemudian mendapatkan promosi jabatan sebagai imbalannya. Sebagaimana hasil wawancara penulis dengan Ketua Panitia Pengawas Pilkada Kota Surakarta, berikut:19

\begin{abstract}
"bahwa beberapa pegawai negeri sipil yang tidak netral biasanya membutuhkan lompatan jabatan karir, dan momentum pilkada adalah waktu yang tepat untuk meraih karir tersebut dengan jalan mendukung secara sembunyi atau dibelakang layar dengan harapan apabila menang tujuan tersebut terwujud. Namun sebaliknya, kalau yang didukung kalah maka karirnya terhambat. Pengangkatan dan pemberhentian pejabat saat ini bukan karena golongan kepangkatan, prestasi kerja dan senioritas dalam daftar urutan kepangkatan, namun promosi jabatan berdasarkan tindakan pegawai negeri sipil mendukung atau tidaknya dalam perhelatan pilkada. Kenyataannya birokrat adalah pejabat karier yang tugasnya banyak ditentukan oleh pejabat politik mulai dari presiden, menteri, gubernur, DPR/DPRD sampai bupati dan walikota. Hal ini sering terjadi setelah bupati/walikota dilantik, tidak lama kemudian pasti mengadakan perombakan jajarannya mulai dari eselon 1 sampai eselon 4 . Pegawai yang merasa sudah berjasa akan mendapatkan kedudukan dan karir yang lebih baik. Hal ini yang membuat PNS berani mempertaruhkan netralitasnya sebagai wujud loyalitas".
\end{abstract}

Hasil wawancara penulis dengan ketua Panitia Pengawas Pilkada Kabupaten Bantul dan Kabupaten Sragen intinya hampir sama, yang kami rangkum sebagai berikut:20

"bahwa jabatan karier merupakan sesuatu yang sangat diinginkan oleh PNS, para camat menginginkan menjadi kabag/kabid. Sedangkan kabag/kabid menginginkan menjadi kepala kantor/dinas. Kepala kantor/dinas menginginkan menjadi asisten atau sekretaris daerah. Maka ambisi untuk menduduki jabatan-jabatan tersebut waktu yang tepat adalah memberikan dukungan kepada calon kepala daerah meskipun mereka tahu bahwa perbuatan ini melanggar netralitas PNS"

\footnotetext{
${ }^{19}$ Wawancara dengan Sri Sumanta, Ketua Panitia Pengawas Pilkada Kota Solo Tahun 2015, pada tanggal 11 Juli 2017

${ }^{20}$ Wawancara dengan Supardi. Ketua Panitia Pengawas Pilkada Kab, Bantul, pada tanggal 26 September 2017. Dan Slamet Basuki Ketua Panwas Kab. Sragen. Pada tanggal 9 Mei 2017
} 


\section{Ambiguitas Peraturan}

Pasal 2 huruf f UU ASN mengatur bahwa penyelenggaraan kebijakan dan manajemen ASN didasarkan pada asas netralitas. Penjelasan pasal tersebut menguraikan bahwa "asas netralitas" adalah bahwa setiap aparatur tidak berpihak dari segala bentuk pengaruh manapun dan tidak memihak kepada kepentingan siapapun. Di sisi lain Pasal 1 angka 2 UU ASN menegaskan bahwa PNS yang merupakan bagian dari ASN selain pegawai pemerintah dengan perjanjian kerja tetap mempunyai hak untuk memilih dalam Pemilihan Umum maupun Pilkada.

Pasal 53 UU ASN juga menimbulkan suatu persoalan yang sangat krusial, mengenai kewenangan bupati/walikota sebagai Pejabat Pembina Kepegawaian untuk menetapkan pengangkatan, pemindahan, dan pemberhentian pejabat yang berada di wilayahnya. Ketentuan tersebut sering menjadi pemicu PNS berbuat tidak netral dalam pelaksanaan pilkada karena unsur loyalitas bawahan terhadap atasan sehingga mengesampingkan aturan.

Kerancuan juga terdapat dalam Peraturan Menteri Pendayagunaan Aparatur Negara dan Reformasi Birokrasi 22 Juli 2015, Nomor : B/2355/M.PANRB/07/2015 tentang Netralitas ASN dan larangan penggunaan aset pemerintah dalam Pemilihan Kepala Daerah secara serentak. Surat edaran ini mengandung ketentuan yang multi tafsir, bahwa setiap ASN dilarang memberikan dukungan kepada kepala daerah/wakil kepala daerah dengan cara "terlibat dalam kegiatan kampanye untuk mendukung calon kepala daerah/wakil kepala daerah". ${ }^{21}$ Kalimat ini multitafsir karena dapat dipahami/ditafsirkan bahwa ASN boleh mengikuti kampanye calon asalkan tidak memberikan dukungan. ASN bisa saja berdalil bahwa kehadirannya dalam kampanye sebatas untuk mengetahui figur, visi, dan misi kandidat. Oleh karena itu, sangat sulit untuk menentukan apakah ASN yang ikut kampanye tersebut memberi dukungan atau tidak.

\section{Lemahnya Penegakan Hukum}

Indonesia adalah negara hukum (rechsstaat) dan bukan negara kekuasaan (maachsstaat). Negara hukum bertujuan melindungi segenap bangsa Indonesia dan seluruh tumpah darah Indonesia, mewujudkan kehidupan masyarakat bangsa dan

${ }^{21}$ Lihat juga Pasal 4 huruf o angka (1) Peraturan Pemerintah Nomor 53 Tahun 2010 tentang Disiplin PNS 
negara yang sejahtera, tertib, aman, damai dan sentosa serta berkeadilan sosial. Konsekuensinya negara harus menempatkan hukum sebagai panglima dan menjadikan satu-satunya alat untuk menyelesaikan segala permasalahan. Kenyataan di lapangan ASN pendukung calon kepala daerah petahana tidak dikenakan sanksi hukum sesuai rekomendasi dari lembaga terkait. Hal ini terjadi saat Camat Jebres Surakarta mendatangi pertemuan warga di salah satu rumah warga di kampung Pucangsawit untuk deklarasi mendukung salah satu calon petahana. Panwaslu merekomendasikan agar camat tersebut diberikan sanksi secara tegas karena melanggar netralitas, namun Walikota justru tidak menjatuhkan sanksi. ${ }^{22}$

Penanganan pelanggaran netralitas masih belum secara jelas diatur, sehingga ada kecenderungan antar lembaga saling melepaskan tanggung jawab jika terjadi pelanggaran. Penanganan pelanggaran digambarkan oleh Ketua Bawaslu Republik Indonesia sebagai serangkaian proses yang meliputi penerusan temuan, penerimaan laporan, pengumpulan alat bukti, klarifikasi, pengkajian dan atau pemberian rekomendasi, serta meneruskan hasil kajian atas temuan atau laporan kepada instansi yang berwenang untuk ditindaklanjuti. ${ }^{23}$ Dengan adanya laporan, maka ditindaklanjuti oleh pengawas pemilu dengan melakukan pengkajian dan pemberkasan serta melengkapi barang bukti pelanggaran. Kemudian dilakukan rapat pleno, apakah laporan dan temuan pelanggaran tersebut masuk dalam ranah bukan pelanggaran, pelanggaran administrasi atau merupakan pelanggaran pidana. ${ }^{24}$

Apabila perbuatan pelanggaran tersebut masuk dalam pelanggaran pidana, maka diproses dengan memberikan rekomendasi kepada pihak kepolisian untuk ditindaklanjuti sesuai hukum yang berlaku. Kemudian Kepolisian sebagai Penyidik berkoordinasi dengan Kejaksaan sebagai Penuntut Umum. Kasus ini terjadi di Kabupaten Sragen dengan pelaku Pelanggaran Pidana seorang ASN Camat Sambirejo yang dinyatakan bersalah oleh Pengadilan Negeri Sragen hanya

\footnotetext{
11 Juli 2017

22 Wawancara dengan Sri Sumanta. Ketua Panitia Pengawas Pilkada Kota Solo Tahun 2015, pada tanggal

${ }^{23}$ Ketua Bawaslu dalam Rapat Koordinasi Nasional dalam Rangka Pemantapan Pelaksanaan Pemilu Presiden dan Wakil Presiden Tahun 2014, Jakarta, tanggal 4 Juni 2014

${ }^{24}$ Wawancara dengan Supardi, Ketua Panwaslu Kabupaten Bantul, DIY tahun 2015, Selasa, 26 Sept. 2017
} 
dijatuhi hukuman penjara 1 bulan dan denda Rp. 1.500.000,00, seharusnya dijatuhi hukuman dan denda maksimal sesuai tuntutan agar bisa menimbulkan efek jera bagi ASN. 25

Lembaga yang menangani pelanggaran pemilu sebetulnya sudah diatur dalam Undang-Undang Pilkada sesuai dengan kriteria permasalahan hukumnya, antara lain : a. Komisi Pemilihan Umum (KPU) menangani jenis pelanggaran terhadap ketentuan administrasi pemilu, yaitu pelanggaran yang selain pelanggaran dalam kategori tindak pidana pemilu dan pelanggaran kode etik pemilu. B. Sentra Gakumdu (Penegakan Hukum Terpadu) yang anggotanya terdiri atas gabungan dari tiga lembaga yaitu Kepolisian, Kejaksaan dan Bawaslu/Panwaslu. Sentra ini menangani jenis ketentuan pelanggaran pidana pemilu. C. Dewan Kehormatan Penyelenggara Pemilu (DKPP), menangani ketentuan pelanggaran kode etik pemilu, mekanisme, prosedur, pedoman beracara dan penyelesainnya. D. Mahkamah Konstitusi (MK), menangani sengketa perselisihan hasil pemilu, prosedur beracara dan cara penyelesainnya. E. Komisi Aparatur Sipil Negara (KASN) merupakan lembaga nonstruktural yang mandiri dan bebas dari intervensi politik untuk menciptakan Pegawai ASN yang profesional dan berkinerja, memberikan pelayanan secara adil dan netral, serta menjadi perekat dan pemersatu bangsa. Tugasnya antara lain menjaga netralitas Pegawai ASN dan melakukan pengawasan serta pembinaan profesi.

Kelima lembaga ini sebenarnya cukup untuk menangani dan menyelesaikan masalah netralitas yang terjadi pada saat Pilkada. Namun yang sering terjadi di lapangan lembaga-lembaga tersebut justru kurang sigap dalam melaksanakan tugas dan tanggung jawabnya. Sebagai salah satu contoh kasus puluhan pejabat di Kabupaten Bantul yang terindikasi tidak netral memberikan dukungan dalam deklarasi, justru Ombudsman yang terlibat menangani kasus netralitas tersebut, padahal Ombudsman bukan lembaga yang berkaitan langsung dengan pelanggaran Pilkada. ${ }^{26}$ UU ASN mengamanatkan 4 (empat) lembaga negara yang diberikan wewenang terkait dengan netralitas yaitu Kementerian Pemberdayaan Aparatur Negara dan Reformasi Birokrasi (Menpan RB), Komisi Aparatur Sipil

25 Wawancara dengan Slamet Basuki Indrowiyono, Ketua Panwas Kab. Sragen, Pada tanggal 9 Mei 2017

26 Wawancara dengan Supardi, Ketua Panwaslu Kabupaten Bantul, DIY tahun 2015, Selasa, 26 Sept. 2017 
Negara (KASN), Lembaga Administrasi Negara (LAN) dan Badan Kepegawaian Negara (BKN). ${ }^{27}$

\section{Kesadaran Masyarakat}

Masyarakat cenderung mengabaikan apabila mengetahui pelanggaran oknum ASN, sehingga banyak kasus pelanggaran netralitas tidak tertangani penegak hukum. Wawancara penulis dengan salah satu sekretaris kantor Pemerintah Daerah Sragen, Agus Sumanto, mengungkapkan bahwa "Sebenarnya kasus netralitas PNS di Kabupaten Sragen tidak hanya Camat Sambirejo dan Agus Tril kepala Bidang Badan Perencanaan Daerah (Bappeda), namun ada banyak Pegawai Negeri Sipil yang mendukung salah satu calon kepala daerah, namun masyarakat enggan atau tidak peduli dengan perbuatan tersebut". 28 Masyarakat tidak mau mengurusi atau tidak peduli, karena untuk melaporkan ASN yang telibat kampanye harus menunjukan bukti-bukti ke Panitia Pengawas Pilkada berupa foto, video dan lainlain.

Kesadaran masyarakat untuk melaporkan ASN yang tidak netral juga dikemukakan oleh Ketua Divisi Penindakan Pelanggaran Panwaslu Bantul, Ibu Harlina mengungkapkan "bahwa PNS yang terdiri dari Sekda, Kepala BKD, Kepala Kantor, Kabag/Kabid, beberapa Camat dan Lurah saat deklarasi memberikan dukungan kepada calon kepala daerah petahana di lapangan Trirenggo Bantul, banyak masyarakat yang mengetahui dan menyaksikan namun mereka enggan melaporkan karena harus memerlukan bukti-bukti yang cukup merepotkan maka mereka tidak peduli"29

Di Solo, keengganan masyarakat untuk lapor juga terjadi saat Lurah Mangkubumen, Lurah Jebres, Lurah Tegalharjo, foto bersama mengacungkan 2 jari memberi dukungan terhadap calon petahana dengan nomor urut 2 saat anggota DPR dari PDIP Aria Bima berkunjung di Surakarta. ${ }^{30}$ Berikut penulis sajikan bukti telah terjadinya pelanggaran netralitas ASN dalam Pilkada di Kota Surakarta, Kabupaten Sragen, dan Kabupaten Bantul.

\footnotetext{
${ }^{27}$ Firman, "Meritokrasi dan Netralitas Aparatur Sipil Negara dalam Pengaruh Pilkada Langsung", Jurnal IJPA-The Indonesian Journal of Public Administration Vol.3 No. 2, Desember 2017, hlm. 15-16

${ }^{28}$ Wawancara dengan Ir. Agus Sumanto, Sekretaris Kantor Perumahan Daerah Kabupaten Sragen. Sabtu, 23 September 2017, pukul 19.30

${ }^{29}$ Wawancara dengan Ibu Harlina. Devisi Penindakan Pelanggaran Panwaslu Bantul. 26 September 2017

30 Wawancara dengan Rahmad Sutomo Kepala BKD Surakarta, di Kantor BKD Selasa 10 Oktober 2017
} 
Tabel 1

Pegawai Negeri Sipil Kota Surakarta Yang Diduga Tidak Netral ${ }^{31}$

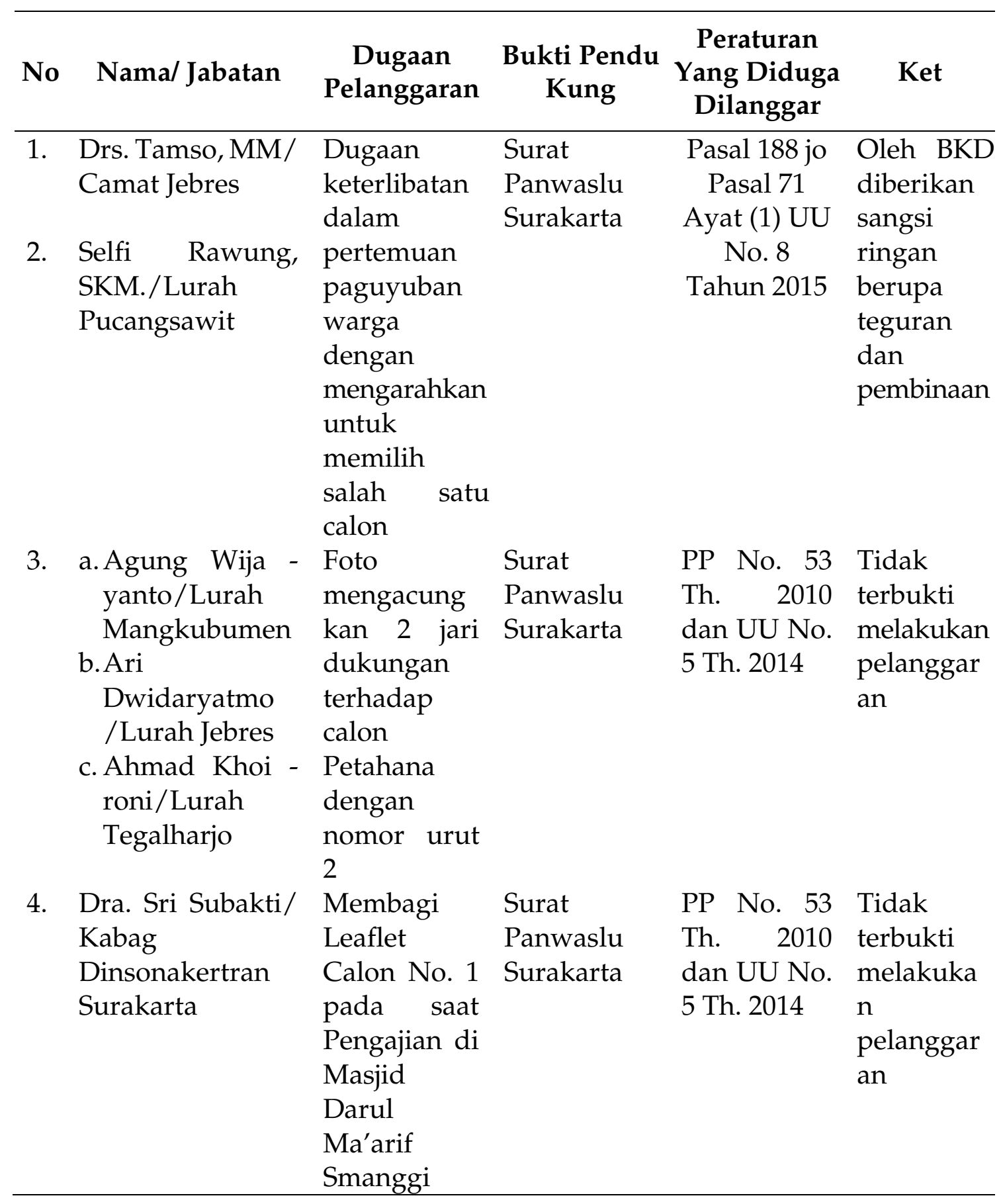

31 Sumber: Panitia Pengawas Pemilihan Walikota dan Wakil Walikota Surakarta Divisi Penanganan Pelanggaran dan wawancara dengan Kepala BKD Kota Surakarta Rahmad Sutomo 
Tabel 2

Pegawai Negeri Sipil Kabupaten Sragen Yang Diduga Tidak Netral ${ }^{32}$

\begin{tabular}{|c|c|c|c|c|c|}
\hline No & Nama/Jabatan & $\begin{array}{c}\text { Dugaan } \\
\text { Pelanggaran }\end{array}$ & $\begin{array}{l}\text { Bukti } \\
\text { Pendu } \\
\text { Kung }\end{array}$ & $\begin{array}{l}\text { Peraturan } \\
\text { Yang } \\
\text { Diduga } \\
\text { Dilanggar }\end{array}$ & Ket \\
\hline 1. & $\begin{array}{l}\text { Drs. Suhariyanto/ } \\
\text { Camat Sambirejo }\end{array}$ & $\begin{array}{l}\text { Paket Sembako } \\
405 \text { bungkus } \\
\text { diberi stiker } \\
\text { Paslon no. } 2 \\
\text { AMAN TO }\end{array}$ & $\begin{array}{l}\text { Laporan } \\
\text { 004/LP/ } \\
\text { Pilbub/X } \\
\text { /2015 }\end{array}$ & $\begin{array}{l}\text { Pasal } 188 \\
\text { jo Pasal } 71 \\
\text { Ayat (1) } \\
\text { UU No. } 8 \\
\text { Tahun } \\
2015 \text { dan } \\
\text { Pasal } 67 \\
\text { ayat (1) } \\
\text { ayat ( 2) } \\
\text { PKPU No. } \\
7 \text { Th. 2015 }\end{array}$ & $\begin{array}{l}\text { Dijatuhi } \\
\text { hukuman } \\
\text { oleh PN } \\
\text { Sragen } 1 \\
\text { bulan } \\
\text { penjara, } \\
\text { denda } 1.5 \\
\text { jt. } \\
\text { subsidier } \\
1 \text { bulan } \\
\text { kurungan }\end{array}$ \\
\hline 2. & $\begin{array}{l}\text { Kepala Desa } \\
\text { Pilangsari } \\
\text { Kecamatan Gesi }\end{array}$ & $\begin{array}{l}\text { Diduga } \\
\text { melakukan } \\
\text { kegiatan yang } \\
\text { berpihak pada } \\
\text { calon } \\
\text { incambent } \\
\text { pada acara } \\
\text { Peresmian } \\
\text { Jembatan } \\
\text { Deren }\end{array}$ & $\begin{array}{l}\text { Temuan } \\
1.09 / \mathrm{TM} \\
\text { /Pilbub/ } \\
\text { IX/2015 }\end{array}$ & $\begin{array}{l}\text { Pasal } 71 \\
\text { ayat (1) jo } \\
\text { Pasal } 188 \\
\text { UU No. } 8 \\
\text { Tahun } \\
2015\end{array}$ & $\begin{array}{l}\text { Tidak } \\
\text { terbukti } \\
\text { melakuka } \\
\text { n } \\
\text { pelanggar } \\
\text { an }\end{array}$ \\
\hline 3. & $\begin{array}{l}\text { Indardi/Kepala } \\
\text { Desa Karangasem } \\
\text { Kecamatan Tanon }\end{array}$ & $\begin{array}{l}\text { Diduga } \\
\text { membuat } \\
\text { keputusan } \\
\text { yang } \\
\text { menguntungka } \\
\text { n salah satu } \\
\text { calon selama } \\
\text { masa } \\
\text { kampanye dan } \\
\text { anggaran } \\
\text { pemerintah } \\
\text { daerah }\end{array}$ & $\begin{array}{l}\text { Laporan } \\
\text { 002/LP/ } \\
\text { Pilbub/I } \\
\text { X/2015 }\end{array}$ & $\begin{array}{l}\text { Pasal } 71 \\
\text { ayat (1) jo } \\
\text { Pasal } 188 \\
\text { UU No. } 8 \\
\text { Th. } 2015 . \\
\text { Pasal } 67 \\
\text { ayat }(1,2) \\
\text { PKPU No. } \\
7 \text { Tahun } \\
\text { 2015. } \\
7 \text { Th. } 2015\end{array}$ & $\begin{array}{l}\text { Dilaporka } \\
\text { n ke } \\
\text { Komisi } \\
\text { ASN. } \\
\text { Satgas } \\
\text { Netralitas } \\
\text { PNS. } \\
\text { Kemenda } \\
\text { griMenpa } \\
\text { n RB., dan } \\
\text { BKN. }\end{array}$ \\
\hline
\end{tabular}

32 Sumber : Panitia Pengawas Pemilihan Bupati dan Wakil Bupati Sragen Divisi Penanganan Pelanggaran 


\begin{tabular}{|c|c|c|c|c|c|}
\hline 4. & $\begin{array}{l}\text { Agus Tri } \\
\text { Lasmono, SIP, } \\
\text { M.Si. } \\
\text { Kabid. Bappeda } \\
\text { Sragen }\end{array}$ & $\begin{array}{l}\text { Keterlibatan } \\
\text { dalam } \\
\text { kampanye } \\
\text { terbuka } \\
\text { Pasangan } \\
\text { Calon No. Urut } \\
2 \text { (Amanto) di } \\
\text { Lapangan } \\
\text { Nglorog, Kab. } \\
\text { Sragen }\end{array}$ & $\begin{array}{l}\text { Laporan } \\
\text { 006/LP/ } \\
\text { Pilbub/X } \\
\text { II/ } 2015\end{array}$ & $\begin{array}{l}\text { Pasal } 67 \\
\text { ayat (1) } \\
\text { Peraturan } \\
\text { KPU No. } 7 \\
\text { Tahun } \\
2015\end{array}$ & $\begin{array}{l}\text { Dilaporka } \\
\mathrm{n} \text { ke } \\
\text { Komisi } \\
\text { ASN, } \\
\text { Mendagri } \\
\text {, Menpan } \\
\text { RB, } \\
\text { Gubernur } \\
\text { dan } \\
\text { Bawaslu } \\
\text { RI }\end{array}$ \\
\hline
\end{tabular}

Tabel 3

Pegawai Negeri Sipil Kabupaten Bantul Yang Diduga Tidak Netral ${ }^{33}$

\begin{tabular}{|c|c|c|c|c|c|}
\hline No & Nama/ Jabatan & $\begin{array}{c}\text { Dugaan } \\
\text { Pelanggaran }\end{array}$ & $\begin{array}{l}\text { Bukti } \\
\text { Pendu } \\
\text { Kung }\end{array}$ & $\begin{array}{c}\text { Peraturan } \\
\text { Yang } \\
\text { Diduga } \\
\text { Dilanggar }\end{array}$ & Ket \\
\hline 1. & $\begin{array}{l}\text { Drs. Riyantoro, } \\
\text { M.Si/Sekda } \\
\text { Bantul }\end{array}$ & $\begin{array}{l}\text { a. Dugaan } \\
\text { keterlibatan } \\
\text { /dukungan }\end{array}$ & $\begin{array}{l}\text { Surat } \\
\text { Panwaslu } \\
\text { Bantul }\end{array}$ & $\begin{array}{l}\text { Peraturan } \\
\text { Pemerinta } \\
\text { h (PP) No. }\end{array}$ & $\begin{array}{l}\text { a. Panwaslu } \\
\text { melakukan } \\
\text { kajian }\end{array}$ \\
\hline 2. & $\begin{array}{l}\text { Drs. Masharun, } \\
\text { MM / Kepala } \\
\text { Dinas Pendidikan } \\
\text { Menengah dan } \\
\text { Non Formal }\end{array}$ & $\begin{array}{l}\text { terhadap } \\
\text { salah satu } \\
\text { Paslon } \\
\text { Bupati yang } \\
\text { dilakukan }\end{array}$ & $\begin{array}{l}\text { Nomor } \\
\text { 004/TM/ } \\
\text { PANWA } \\
\text { SKAB- } \\
\text { BTL/VII }\end{array}$ & $\begin{array}{l}53 / 2010 . \\
\text { Tentang } \\
\text { Disiplin } \\
\text { PNS. Pasal } \\
\text { 4. Ayat } 15\end{array}$ & $\begin{array}{l}\text { menyimpul } \\
\text { kan bukan } \\
\text { merupakan } \\
\text { pelanggara } \\
\text { n karena }\end{array}$ \\
\hline 3. & \begin{tabular}{lr}
\multicolumn{2}{l}{ Edy Machdun / } \\
Kepala & Dinas \\
Kelautan & dan \\
Perikanan &
\end{tabular} & $\begin{array}{l}\text { oleh SKPD, } \\
\text { Camat, } \\
\text { Lurah dan } \\
\text { Perangkat }\end{array}$ & $\begin{array}{l}\text { /2015, } \\
\text { yang } \\
\text { ditujukn } \\
\text { kepda Pj. }\end{array}$ & $\begin{array}{l}\text { huruf a, } \\
\text { mengenai } \\
\text { PNS } \\
\text { dilarang }\end{array}$ & $\begin{array}{l}\text { kejadian } \\
\text { sebelum } \\
\text { tahapan } \\
\text { pencalonan }\end{array}$ \\
\hline 4. & $\begin{array}{l}\text { Bambang } \\
\text { Purwasi } \\
\text { Nugroho/Inspek } \\
\text { torat }\end{array}$ & $\begin{array}{l}\text { Desa. } \\
\text { b. Dugaan } \\
\text { diawali } \\
\text { dengan }\end{array}$ & $\begin{array}{l}\text { Bupati } \\
\text { Bantul, } \\
\text { perihal } \\
\text { penerusa }\end{array}$ & $\begin{array}{l}\text { terlibat } \\
\text { dalam } \\
\text { memberik } \\
\text { andukung }\end{array}$ & $\begin{array}{l}\text { dan } \\
\text { kampanye. } \\
\text { b. Terhadap } \\
\text { dugaan }\end{array}$ \\
\hline 5. & $\begin{array}{l}\text { Sigit Widodo / } \\
\text { Kabag Organisasi } \\
\text { Danang }\end{array}$ & $\begin{array}{l}\text { kedatangan } \\
\text { Ybs., dalam } \\
\text { acara } \\
\text { deklarasi } \\
\text { yang dilaku- } \\
\text { kan oleh }\end{array}$ & n. & $\begin{array}{l}\text { an/ } \\
\text { mendukun } \\
\text { g salah } \\
\text { satu } \\
\text { Pasangan }\end{array}$ & $\begin{array}{l}\text { pelanggara } \\
\mathrm{n} \text { netralitas } \\
\text { ASN } \\
\text { Panwas } \\
\text { menyerahk } \\
\text { an kepada }\end{array}$ \\
\hline
\end{tabular}

33Sumber : Panitia Pengawas Pemilihan Bupati dan Wakil Bupati Kabupaten Bantul dan wawancara dengan Sekretaris BKD Pemkab Bantul Imam Subardiyoso 


\begin{tabular}{|c|c|c|c|c|c|}
\hline \multirow[t]{2}{*}{6.} & Erwanto/ Kabag & PDI & & Calon & instansi \\
\hline & Tapem & Perjuangan & & Kepala & berwenang \\
\hline 7. & $\begin{array}{l}\text { Supriyanto/ } \\
\text { Kepala BKD }\end{array}$ & $\begin{array}{l}\text { yang } \\
\text { mengusung }\end{array}$ & & Daerah & $\begin{array}{l}\text { untuk } \\
\text { menindak }\end{array}$ \\
\hline 8. & $\begin{array}{l}\text { Sunarto/ Asisten } \\
\text { Adm Umum }\end{array}$ & $\begin{array}{l}\text { Hj. Sri Surya } \\
\text { Widati dan }\end{array}$ & & & $\begin{array}{l}\text { lanjuti. } \\
\text { c. BKN }\end{array}$ \\
\hline \multirow[t]{5}{*}{9.} & Partologi Dame & Drs. & & & menyataka \\
\hline & Pakpahan/ & Misbachul & & & $\mathrm{n}$ perbuatar \\
\hline & Kepala Dinas & Munir, M.Si. & & & tersebut \\
\hline & Pertanian dan & sebagai & & & merupakan \\
\hline & Kehutanan & Bakal Calon & & & pelanggara \\
\hline \multirow[t]{4}{*}{10.} & Supriyanto & Bupati dan & & & $\mathrm{n}$ disiplin \\
\hline & Widodo /Kepala & Wakil & & & PNS dan \\
\hline & Kantor Pemuda & Bupati & & & meminta \\
\hline & dan Olahraga & Bantul 2015. & & & kepada Pj. \\
\hline \multirow[t]{3}{*}{11.} & Slamet Santoso / & Pada hari & & & Bupati \\
\hline & Kepala Kantor & Minggu & & & Bantul utk \\
\hline & Pengelola Pasar & tanggal 14 & & & menindak \\
\hline \multirow[t]{3}{*}{12.} & Totok Sudarto / & Juni 2015 di & & & lanjuti \\
\hline & Ka Dinas & Lapangan & & & pelanggara \\
\hline & Pendidikan Dasar & Trirenggo & & & n tersebut. \\
\hline \multirow[t]{3}{*}{13.} & Jati Bayu Broto / & Kec. Bantul & & & Panwaslu \\
\hline & Camat & Kab. Bantul & & & mengirim \\
\hline & Banguntapan & mulai pukul & & & kan surat \\
\hline \multirow[t]{3}{*}{14.} & Drs. Fatoni/ & $14.00-17.00$ & & & kepada $\mathrm{Pj}$ \\
\hline & Camat Sanden & WIB. & & & Bupati \\
\hline & & & & & $\begin{array}{l}\text { Bantul utk } \\
\text { ditindak } \\
\text { lanjuti }\end{array}$ \\
\hline \multirow[t]{11}{*}{15.} & Subagyo Hadi/ & Dugaan & Rekomen & Peraturan & \\
\hline & Lurah Canden & keterlibatan & dasi & Pemerinta & \\
\hline & & Lurah dengan & Panwasl & h (PP) No. & \\
\hline & & menyediakan & u Bantul & $53 / 2010$ & \\
\hline & & rumahnya & 002/TM/ & Tentang & \\
\hline & & untuk & PANWA & Disiplin & \\
\hline & & musyawarah & SCAM- & PNS. Pasal & \\
\hline & & ranting khusus & JTS/VIII & 4. Ayat 15 & \\
\hline & & PDIP Desa & $/ 2015$ & huruf a. & \\
\hline & & $\begin{array}{l}\text { Canden pada } \\
\text { tanggal } 11\end{array}$ & & & \\
\hline & & Agustus 2015 & & & \\
\hline
\end{tabular}




\section{Upaya Mewujudkan Netralitas Aparatur Sipil Negara dalam Pemilihan Kepala Daerah}

Selain beberapa faktor yang menghambat pewujudan netralitas ASN di atas, Tatang Sudrajat juga mengemukakan bahwa sebenarnya ada beberapa komponen yang dapat mendukung upaya mewujudkan netralitas ASN ini. ${ }^{34}$ Beberapa komponen penulis analisis dengan mengaitkannya terhadap konteks kasus yang relatif terjadi dalam Pilkada.

\section{Komisi Aparatur Sipil Negara (KASN)}

Sebagai bagian dari aparatur sipil negara, ASN mustahil akan terbebas dari pengaruh dan intervensi dari calon kepala daerah incumbent/petahana. ASN sebagai pelaksana kebijakan publik, pelayan publik serta perekat dan pemersatu bangsa sebagaimana disebut dalam Pasal 10 Undang-Undang Nomor 5 Tahun 2014, hanya akan menjadi harapan yang hampa, apabila tidak ada konsistensi dari berbagai pihak untuk turut menaati peraturan mengenai netralitas birokrasi. Tumpuan besar terletak pada KASN yang diantaranya menurut ketentuan Pasal 31 ayat (1) UU ASN bertugas menjaga netralitas ASN. Sebagai lembaga nonstuktural yang mandiri dan bebas dari intervensi politik, KASN menjadi harapan bagi reformasi birokrasi. Salah satu kewenangannya sebagaimana diatur dalam Pasal 32 ayat (1) UU ASN adalah mengevaluasi penerapan asas, nilai dasar, serta kode etik dan kode perilaku ASN. Harapan besar publik tertuju pada lembaga ini agar konsisten menegakkan berbagai peraturan perundang-undangan dalam mewujudkan netralitas PNS. Uji validitas dari 3 lokasi penulis belum menemukan keputusan dari Komisi ASN terkait laporan pelanggaran netralitas ASN. Meskipun seperti Kabupaten Sragen telah melaporkan Kepala Bidang Bappeda dan seorang Lurah di Kecamatan Tanon. KASN memiliki peran dalam upaya pewujudan netralitas ASN, sebagaimana tergambar dalam bagan berikut.

\footnotetext{
34 Tatang Sudrajat, "Netralitas PNSdan Masa DepanDemokrasidalamPilkadaSerentak 2015”, Jurnal Ilmu Administrasi: Media Pengembangan Ilmu dan Praktek Administrasi, Vol. XII, No.3, Desember 2015, hlm.351-370
} 
Bagan Alur Tindak Lanjut Pelaporan ke Komisi ASN

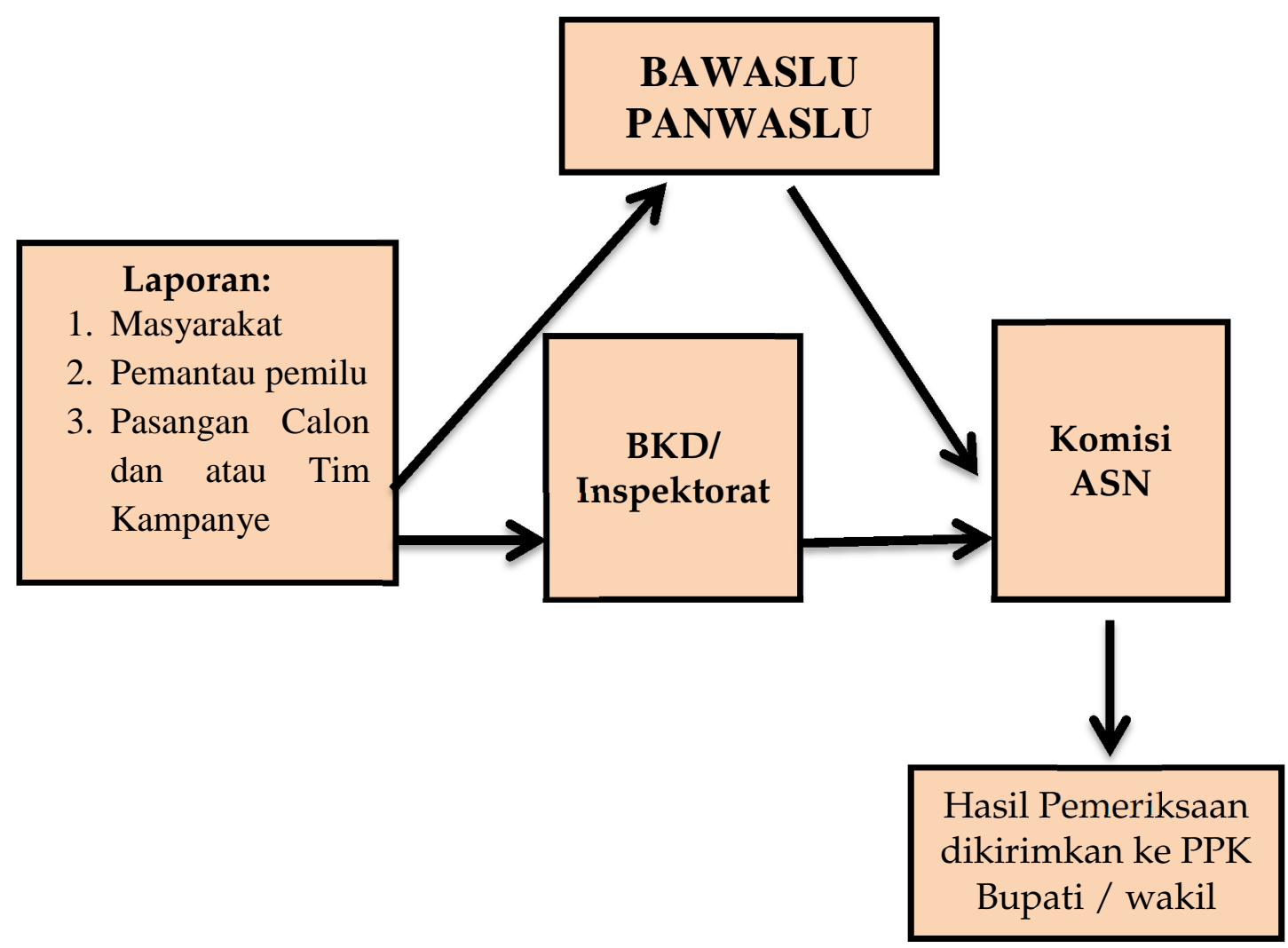

\section{Pimpinan Birokrasi}

Pejabat publik yang pada hakikatnya merupakan pimpinan puncak birokrasi di daerah, yaitu gubernur, bupati, walikota termasuk wakilnya wajib mendukung upaya mewujudkan netralitas ASN dalam Pilkada. Pemanfaatan birokrasi untuk kepentingan politik harus dihentikan karena bukan saja merusak citra ASN sebagai aparatur negara tetapi juga merugikan kepentingan publik. ASN jangan sampai terus menerus dijadikan 'sapi perahan' untuk mengais keuntungan politik. Upaya ini tentu memerlukan komitmen iktikad baik dari pejabat yang bersangkutan.

Undang-Undang Nomor 1 Tahun 2015 tentang Penetapan Peraturan Pemerintah pengganti Undang-Undang No. 1 Tahun 2014 tentang Pemilihan Gubernur, Bupati dan Walikota menjadi Undang-Undang, mengatur bahwa gubernur, bupati dan walikota yang menjadi peserta pilkada dalam melaksanakan kampanye tidak boleh menggunakan fasilitas yang terkait dengan jabatannya. Pejabat negara dilarang membuat keputusan dan/atau tindakan yang menguntungkan atau merugikan salah satu pasangan calon selama masa 
kampanye. Ketauladanan pemimpin dengan tidak memobilisasi ASN dalam pilkada harus menjadi bagian integral dalam mendukung reformasi birokrasi.

Sebagai pejabat publik, seharusnya sadar terhadap ketentuan Pasal 67 huruf c Undang-Undang 23 Tahun 2014 tentang Pemerintahan Daerah bahwa kewajiban kepala daerah adalah mengembangkan kehidupan demokrasi. Bukan demokrasi yang berkembang apabila di daerahnya justru terjadi praktik-praktik politik yang menodai kehidupan berdemokrasi dengan cara memobilisasi aparatur untuk kemenangannya sebagai kepala daerah. Upaya untuk mewujudkan netralitas birokrasi ini harus dilakukan baik di tingkat pemerintahan pusat maupun pemerintahan daerah.

Upaya ini sebagian kecil telah dilakukan dibeberapa daerah, khususnya di lokasi penelitian penulis. Kasus di Surakarta, Walikota memberikan sanksi kepada salah satu Camat dan Lurah yang terlibat dalam kontestasi Pilkada dengan memberikan peringatan berupa teguran dan pembinaan. ${ }^{35}$ Begitu juga di Bantul, Bupati memberi peringatan dengan meminta para pejabat yang terbukti melakukan pelanggaran netralitas untuk membuat surat pernyataan bermaterai bahwa tidak akan mengulangi kembali perbuatannya. ${ }^{36}$ Di Kabupaten Sragen, Bupati selain memberikan teguran juga melaporan ke Komisi ASN, Satgas Netralitas PNS, Kementerian Dalam Negeri, Menpan RB dan Badan Kepegawaian Negara. ${ }^{37}$ Dengan adanya tindakan tegas dan sanksi nyata yang betul-betul diberikan oleh Pimpinan Birokrasi yaitu Walikota maupun Bupati baik berupa teguran, pembinaan, membuat surat pernyataan maupun melaporkan para PNS yang tidak netral ke Komisi ASN kedepannya akan membuat jera aparatur yang hendak melibatkan diri dalam kostestasi Pilkada.

\section{Komisi Pemilihan Umum (KPU)}

Sebagai penyelenggara Pemilu dan Pilkada, KPU memiliki peran penting untuk mendorong terciptanya suasana kondusif bagi terwujudnya netralitas ASN. Penyelenggara Pemilu tidak secara khusus mengatur tentang tugas, wewenang, dan kewajibannya dalam mewujudkan netralitas ini, tetapi secara moral ada yang dapat dilakukan untuk itu.

\footnotetext{
35 Wawancara dengan Kepala BKD Kota Surakarta Bapak Rohmad Sutomo, Selasa 10 Oktober 2017

36 Wawancara denga Sekretaris BKD Kab. Bantul Bapak Imam Subardiyoso, 26 September 2017

${ }^{37}$ Wawancara dengan Slamet Basuki Indrowiyono, Ketua Panwas Kab. Sragen, Pada tanggal 9 Mei 2017
} 
Sebagai langkah preventif, misalnya KPU dapat mengingatkan Ketua Korp Pegawai Negeri Republik Indonesia (KORPRI) di masing-masing tingkatan daerah untuk konsisten dalam memelihara netralitas ini. Pasal 6 huruf h Pasal 8 Peraturan Pemerintah Nomor 42 Tahun 2004 tentang Pembinaan Jiwa Korps dan Kode Etik PNS, serta Pasal 4 Peraturan Pemerintah Nomor 53 Tahun 2010 tentang Disiplin PNS.

\section{Badan Pengawas Pemilu (Bawaslu)}

Badan Pengawas Pemilu RI (Bawaslu), Bawaslu Provinsi serta Bawaslu Kabupaten/ Kota sampai dengan jajaran pengawas pada tingkat Tempat Pemungutan Suara (TPS), mempunyai tugas untuk mengawasi penyelenggaraan Pemilu termasuk Pilkada sesuai tingkatannya. Pengawasan Pilkada yang dilakukan secara serentak pada tahun 2015 dan 2017 tentu saja menguras energi bagi jajaran pengawas di setiap tingkatan. Strategi pengawasan yang bersifat preventif sebaiknya menjadi prioritas, sehingga berbagai peluang dan potensi pelanggaran pilkada dapat diidentifikasi lebih awal. Interelasi antara hukum, demokrasi dan politik terjelma dalam konsep netralitas bagi ASN.

Tidak dapat dipungkiri bahwa pelanggaran terhadap berbagai tahapan penyelenggaraan Pilkada selama ini, secara terbuka atau terselubung, baik langsung maupun tidak langsung sering terjadi. Berbagai langkah represif sebagai tindak lanjut adanya temuan dan laporan dugaan pelanggaran harus dengan sigap dan segera ditangani oleh jajaran pengawas Pilkada sesuai tingkatannya. Integritas para pengawas sangat dipertaruhkan, karena biasanya masih muncul sikap dan perilaku ewuh pekewuh terhadap para terduga pelaku pelanggaran yang secara kebetulan sedang menjadi kepala daerah atau wakil kepala daerah petahana. Sikap profesionalitas Bawaslu sangat dituntut untuk mewujudkan ASN yang bebas dari kepentingan politik.

\section{Penutup}

Berdasarkan penyajian hasil penelitian dan pembahasan di atas, dapat disimpulkan bahwa ketidaknetralan ASN dalam Pilkada di Kota Surakarta, Kabupaten Sragen dan Kabupaten Bantul terjadi akibat dipengaruhi oleh sejumlah faktor antara lain faktor loyalitas ASN adanya hubungan kekeluargaan, ambisi karir jabatan, ambiguitas peraturan, lemahnya penegakan hukum, serta masih 
rendahnya kesadaran masyarakat untuk turut melaporkan temuan ASN yang diduga terlibat dalam kontestasi Pilkada. Pewujudan netralitas ASN dalam Pilkada dapat dilakukan dengan melibatkan secara optimal peranan beberapa institusi terkait, antara lain Komisi Aparatur Sipil Negara (KASN), Pimpinan Birokrasi, Komisi Pemilihan Umum (KPU), dan Badan Pengawas Pemilu (Bawaslu).

Penulis mengajukan saran agar sebaiknya yang memiliki kewenangan untuk menetapkan pengangkatan, pemindahan, dan pemberhentian ASN bukan lagi pejabat politik yaitu Bupati/Walikota, namun pejabat karir tertinggi di daerah yaitu Sekretaris Daerah dengan pertimbangan Badan Pertimbangan Jabatan dan Kepangkatan (Baperjakat). Hal ini dimaksudkan agar pejabat politik tidak lagi melakukan intervensi terhadap kebijakan kepegawaian. Selain itu, lembaga yang melaporkan pelanggaran seharusnya adalah unsur pengawas pemilu atau unsur pengawas di kantor/lembaga/dinas/kabupaten/kota atau instansi masing-masing. Lembaga yang menentukan dan menetapkan jenis pelanggaran adalah BKD, Inspektorat dan BKN. Sedangkan yang memberikan sanksi kepada ASN berdasarkan rekomendasi adalah Bupati/Walikota atau Pejabat Bupati/Pejabat Walikota.

\section{Daftar Pustaka}

\section{Buku}

Ali. M. Metodologi Penelitian Hukum. Unesa University Press. Surakarta, 2009.

Dalim, Sudiman. Politisasi Birokrasi Netralitas dan Mobilitas PNS dalam Pilkada. Pena Abadi., Jakarta, 2010.

Mahfud, Moh. Evaluasi Pemilukada dalam Perspektif Demokrasi dan Hukum. Dalam Demokrasi Lokal Evaluasi Pemilukada di Idonesia, Konstitusi Press, Jakarta, 2012.

Supriyanto Didik.Penataan Kembali Sistem Pemilihan dalam Pemilukada. Dalam Demokrasi Lokal, Konpress, Jakarta, 2012.

Usman, Sabian.. Dasar-dasar Sosiologi Hukum; Dilengkapi Proposal Penelitian Hukum (Legal Reseacht), Pustaka Pelajar, Yogyakarta, 2010.

Warasih Esmi, Pranata Hukum Sebuah Telaah Sosiologis, Pustaka Magister, Semarang, 2014.

\section{Jurnal}

Firman, "Meritokrasi dan Netralitas Aparatur Sipil Negara dalam Pengaruh Pilkada Langsung", Jurnal IJPA-The Indonesian Journal of Public Administration Vol. 3 No. 2, Desember 2017. 
Firnas, M. Adian, "Politik dan Birokrasi: Masalah Netralitas Birokrasi di Indonesia Era Reformasi" Jurnal Review Politik Vol 06 No. 01, Juni 2016.

Hartini, Sri "Penegakan Hukum Netralitas Pegawai Negeri Sipil (PNS)" Jurnal Dinamika Hukum Vol. 9. No. 3, September 2009.

Nugraha, Harry Setya, "Politik Hukum Pengaturan Netralitas ASN dalam Pilkada Tahun 2018", Jurnal Justisi Hukum ISSN2528-2638 Vol 3, No. 1, September 2018.

Riri Nazriah, Implikasi Putusan MK Terhadap Netralitas PNS dalam Pemilihan Kepala Daerah Jurnal Konstitusi, Volume. 6. Nomor 2, Juli 2008.

Tatang Sudrajat. "Netralitas PNS dan Masa Depan Demokrasi dalam Pilkada Serentak 2015", Jurnal Ilmu Administrasi, Media Pengembangan Ilmu dan Praktek Administrasi. Volume XII, No. 3 Desember 2015.

\section{Peraturan Perundang-Undangan}

Undang-Undang Nomor 5 Tahun 2014 tentang Aparatur Sipil Negara (ASN)

Undang-Undang Nomor 1 Tahun 2015. Jo. UU Nomor 8 Tahun 2015. Jo. UU Nomor 10 Tahun 2016 tentang Pemilihan Kepala Daerah

Undang-Undang Nomor 23 Tahun 2014 tentang Pemerintah Daerah

Peraturan Pemerintah Nomor 53 Tahun 2010 tentang Disiplin Pegawai Negeri Sipil 